\title{
Effects of Silicon Applications on Soybean Rust Development Under Greenhouse and Field Conditions
}

E. M. Lemes, Department of Plant Pathology, University of Florida-IFAS, Gainesville 32611; C. L. Mackowiak, North Florida Research and Educational Center, University of Florida, Quincy 32351; A. Blount, North Florida Research and Educational Center, University of Florida, Marianna 32446; J. J. Marois and D. L. Wright, North Florida Research and Educational Center, University of Florida, Quincy; L. Coelho, Instituto de Ciências Agrárias, Universidade Federal de Uberlândia 38400-902, Brazil; and L. E. Datnoff, Department of Plant Pathology, University of Florida-IFAS, Gainesville

\begin{abstract}
Lemes, E. M., Mackowiak, C. L., Blount, A., Marois, J. J., Wright, D. L., Coelho, L., and Datnoff, L. E. 2011. Effects of silicon applications on soybean rust development under greenhouse and field conditions. Plant Dis. 95:317-324.

Soybean rust (SBR), caused by Phakopsora pachyrhizi, is one of the most destructive fungal diseases affecting soybean production. Silicon (Si) amendments were studied as an alternative strategy to control SBR because this element was reported to suppress a number of plant diseases in other host-pathogen systems. In greenhouse experiments, soybean cultivars inoculated with $P$. pachyrhizi received soil applications of wollastonite $\left(\mathrm{CaSiO}_{3}\right)\left(\mathrm{Si}\right.$ at $0,0.96$, and $\left.1.92 \mathrm{t} \mathrm{ha}^{-1}\right)$ or foliar applications of potassium silicate $\left(\mathrm{K}_{2} \mathrm{SiO}_{3}\right)(\mathrm{Si}$ at $0,500,1,000$, or $2,000 \mathrm{mg} \mathrm{kg}^{-1}$ ). Greenhouse experiment results demonstrated that $\mathrm{Si}$ treatments delayed disease onset by approximately 3 days. The area

ments also was significantly lower than the AUDPC of non-Si-treated plants. For field experiments, an average 3-day delay in disease onset was observed only for soil Si treatments. Reductions in AUDPC of up to 43 and $36 \%$ were also observed for soil and foliar Si treatments, respectively. Considering the natural delayed disease onset due to the inability of the pathogen to overwinter in the major soybean production areas of the United States, the delay in disease onset and the final reduction in AUDPC observed by the soil Si treatments used may lead to the development of SBR control practices that can benefit organic and conventional soybean production systems.
\end{abstract} under disease progress curve (AUDPC) of plants receiving Si treat-
Soybean rust (SBR), caused by Phakopsora pachyrhizi Syd. \& P. Syd. (Urediniomycetes, Uredinales), also known as Asian soybean rust, is a potentially devastating fungal disease that threatens commercial and organic soybean (Glycine max (L.) Merr.) production worldwide (35). Severe SBR damage on soybean is a consequence of windborne urediniospores, susceptible host plants with conducive environmental conditions at the time of infection, and the subsequent crop and pathogen development $(13,14,16)$. A minimum of a 6-h dew period and temperatures ranging from approximately 15 to $29^{\circ} \mathrm{C}$ are necessary for urediniospore infection $(21,27,28)$. The main effects of $P$. pachyrhizi on soybean development are a reduction in photosynthetic leaf area, early plant maturation, and premature defoliation, with low individual seed weight and overall yield reductions (49). Related to this, high levels of SBR infection result in plants with fewer pods and poor seed quality (5); specifically, lower protein (34).

Breeding single-gene resistance to control SBR in soybean has not proven durable (20); therefore, the most adequate option in managing an SBR epidemic is through the application of fungicides, such as triazoles and strobirulins, which substantially increase overall production costs. However, even with chemical control, in years of high SBR pressure, yield reductions of approximately $50 \%$ were observed (52).

An alternative approach to manage plant disease and reduce the extensive use of fungicides is through nutrient management strate-

Corresponding author: L. E. Datnoff, E-mail: LDatnoff@agcenter.lsu.edu

Current address of L. E. Datnoff: Department of Plant Pathology and Crop Physiology, Louisiana State University Agricultural Center, Baton Rouge 70803 .

Accepted for publication 18 November 2010.

doi:10.1094/PDIS-07-10-0500

(C) 2011 The American Phytopathological Society gies. Mineral nutrition plays an important role in the physiological functioning of plants, and has been shown to be an important component for managing plant disease (8). Silicon ( $\mathrm{Si}$ ), supplied as $\mathrm{H}_{4} \mathrm{SiO}_{4}$, has been reported to increase plant resistance to biotic stresses (disease and insects) and improve plant tolerance against abiotic disturbances $(8,10,23,25,26,40)$.

Yield gains in plants supplied with $\mathrm{Si}$ have been attributed to several factors, such as increased plant growth, improved mineral nutrient balance, and mechanical strength. These benefits also provide the plant some resistance to various environmental stresses $(8,10,42)$. Elevated $\mathrm{Si}$ content in plants known to accumulate $\mathrm{Si}$, such as rice (Oryza sativa L.), sugarcane (Sacharum spp. L.), and wheat (Triticum aestivum L.), is associated with higher yields (6). Si fertilization also has reduced fungal disease susceptibility for a number of monocotyledonous and several dicotyledonous plant species $(8,29,49)$. Rice fields amended with $\mathrm{Si}$ had lower incidences of neck blast (Magnaporthe grisea (T.T. Hebert) M.E. Barr) that, in turn, reduced or eliminated fungicide applications (44-46) The application of foliar Si sprays reduced the number of powdery mildew (Uncinula necator (Schwein.) Burrill) colonies on grape (Vitis vinifera L.) leaves and considerably increased yield $(4,38)$. In greenhouse studies with cucumber (Cucumis sativus L.), soluble potassium silicate $\left(\mathrm{K}_{2} \mathrm{SiO}_{3}\right)$ applications showed positive correlations with resistance to powdery mildew (Sphaerotheca fuliginea (Schltdl.) Pollacci) (3,29). Liang et al. (24) found that root or foliar Si applications reduced disease severity and that only the root $\mathrm{Si}$ application enhanced the activity of pathogenesis-related proteins in cucumber.

Studies including soybean and Si fertilization are scarce. Some studies evaluated nutrient toxicity ( $\mathrm{Al}$ and $\mathrm{Mn}$ ) and physiological effects and showed that soybean responded positively to Si amendments $(1,18,22,30)$. Under Si-free conditions, soybean plants displayed malformations such as leaf curling of newly developed leaves (seventh and eighth leaves) during flowering (30). They also reported necrotic spots on soybean leaves and low pollen fertility in cases of severe Si deficiency. In other studies, the use of potassium silicate sprays against SBR on soybean was tested with 
considerable success, and up to $70 \%$ reduction in SBR severity was observed in some cases $(32,41)$. In comparison, Nolla et al. (33), based on only one disease evaluation, reported that soil Si applications were not effective in suppressing SBR development. However, they found that $\mathrm{Si}$ applications reduced the incidence of frog eye (Cercospora sojina Hara) and downy mildew (Peronospora manshurica (Naumov) Syd.).

Because Si amendments have been demonstrated to enhance resistance to a number of plant diseases, and some research suggests that Si may suppress SBR development in soybean, the objective of this study was to evaluate the efficacy of $\mathrm{Si}$ via soil $\left(\mathrm{CaSiO}_{3}\right)$ or foliar $\left(\mathrm{K}_{2} \mathrm{SiO}_{3}\right)$ applications as a means to reduce SBR severity in two soybean maturity groups under greenhouse and field conditions in Florida.

\section{Materials and Methods}

Treatments and cultural conditions. Greenhouse experiments. Two greenhouse experiments were conducted in summer 2007 and 2008. Greenhouse temperatures and humidity averages for both experiments were $28^{\circ} \mathrm{C}$ and $80 \%$. Two soybean cultivars were tested in the first greenhouse experiment: DP5634RR, which is glyphosate (Roundup-Ready) resistant, maturity group 5; and Hinson Long Juvenile, which is a forage soybean, maturity group 8 . In the second greenhouse experiment, only the DP5634RR cultivar was tested.

Free-draining plastic pots were filled with $0.85 \mathrm{~kg}$ of a potting mix (Hyponex potting soil; Hyponex Corp., Maryville, $\mathrm{OH}$ ) for the first greenhouse experiment. In the second experiment, free-draining plastic pots were filled with $1.5 \mathrm{~kg}$ of an Ultisol soil (fineloamy, kaolinitic, thermic Plinthic Kandiudult, Tifton series). The potting mix and soil chemical compositions are presented in Table 1. Three soybean seeds were sown per pot and thinned to one plant per pot at 10 days after planting (DAP). The plants were watered as needed, typically once per day.

Soil-applied Si. Vansil W-50 (Vanderbilt Co., Norwalk, CT) is a fine-grade (talc-like) form of the naturally occurring mineral ore, wollastonite $\left(\mathrm{CaSiO}_{3}\right)$, with a median particle diameter of $2.8 \mu \mathrm{m}$. It contained approximately $24 \% \mathrm{Si}$ and $34 \% \mathrm{Ca}$. The Vansil W-50 wollastonite in slurry $(10 \% \mathrm{wt} / \mathrm{wt})$ had a $\mathrm{pH}$ of 10 to 11 . Dry Vansil $\mathrm{W}-50$ was mixed with the potting substrate at rates of Si equivalent to 0 (control), 0.96 , and $1.92 \mathrm{t} \mathrm{ha}^{-1}$ or W-50 at 0,4 , and $8 \mathrm{t} \mathrm{ha}^{-1}$ (wollastonite at 0,2 , and $4 \mathrm{~g} \mathrm{pot}^{-1}$ ) for the first greenhouse experiment. For the second greenhouse experiment, the soil was amended with Si rates of 0 (control) and $1.92 \mathrm{t} \mathrm{ha}^{-1}$ (W-50 at 0 and $8 \mathrm{t} \mathrm{ha}^{-1}$ ), which equated to $\mathrm{Si}$ at 0 and $0.96 \mathrm{~g} \mathrm{pot}^{-1}$ (wollastonite at 0 and $4 \mathrm{~g}$ $\left.\operatorname{pot}^{-1}\right)$.

A $\mathrm{Ca}(\mathrm{OH})_{2}$ control treatment was included in both greenhouse experiments to account for liming and $\mathrm{Ca}$ effects of the wollastonite treatments. Four grams of hydrated lime $\left(\mathrm{Ca}(\mathrm{OH})_{2} ;\right.$ Lime \&

Table 1. Soil analysis of the potting mix and soil used in the first and second greenhouse experiments, respectively

\begin{tabular}{lcc}
\hline Parameter & Potting mix $^{\mathbf{y}}$ & Ultisol $^{\mathbf{z}}$ \\
\hline $\mathrm{P}$ & $137 \mathrm{mg} \mathrm{kg}^{-1}$ & $\ldots$ \\
$\mathrm{K}$ & $469 \mathrm{mg} \mathrm{kg}^{-1}$ & $\ldots$ \\
$\mathrm{Ca}$ & $3,163 \mathrm{mg} \mathrm{kg}^{-1}$ & $1,221 \mathrm{mg} \mathrm{kg}^{-1}$ \\
$\mathrm{Mg}$ & $233 \mathrm{mg} \mathrm{kg}^{-1}$ & $117 \mathrm{mg} \mathrm{kg}^{-1}$ \\
$\mathrm{~S}$ & $142 \mathrm{mg} \mathrm{kg}^{-1}$ & $\ldots$ \\
$\mathrm{B}$ & $0.9 \mathrm{mg} \mathrm{kg}^{-1}$ & $\ldots$ \\
$\mathrm{Zn}$ & $7.9 \mathrm{mg} \mathrm{kg}^{-1}$ & $\ldots$ \\
$\mathrm{Fe}$ & $153 \mathrm{mg} \mathrm{kg}^{-1}$ & $\ldots$ \\
$\mathrm{Cu}$ & $2 \mathrm{mg} \mathrm{kg}^{-1}$ & $\ldots$ \\
$\mathrm{Mn}$ & $9.5 \mathrm{mg} \mathrm{kg}^{-1}$ & $\ldots$ \\
Water pH $(1: 2$, vol/vol $)$ & 6.8 & 6.7 \\
Organic matter & $4 \%$ & $\ldots$ \\
Cation exchange capacity & $18.9 \mathrm{meq}^{-100 ~ g}$ & $\ldots$ \\
Soil Si & $12 \mathrm{mg} \mathrm{kg}$ & $29 \mathrm{mg} \mathrm{kg}$ \\
\hline
\end{tabular}

${ }^{y}$ Mehlich-1 method was used to extract potting mix nutrients.

${ }^{\mathrm{z}}$ Acetic acid $(0.5 \mathrm{~N})$ was used to extract $\mathrm{Ca}$ and $\mathrm{Mg}$ from the soil and $\mathrm{Si}$ from both substrates.
Cement Co., Allgood, AL) were added per pot $\left(\mathrm{Ca}(\mathrm{OH})_{2}\right.$ at $8 \mathrm{tha}^{-1}$ or $\mathrm{Ca}$ at $4.3 \mathrm{t} \mathrm{ha}^{-1}$ ). The hydrated lime had a $\mathrm{pH}$ of 12.4 (saturated solution at $25^{\circ} \mathrm{C}$ ).

Foliar-applied Si. A foliar solution of potassium silicate, $\left(\mathrm{K}_{2} \mathrm{SiO}_{3}\right.$; AgSil 25; PQ Corp., Valley Forge, PA) was also tested. AgSil 25 is a readily soluble silicate used as a foliar spray and containing approximately $9.7 \% \mathrm{Si}$, with a $\mathrm{pH}$ of 11.3 . An atomizer with propellant cartridge (Sprã-tool; Arvoe Industries Inc., Gardnerville, NV) was used to apply foliar Si treatments to both leaf surfaces until point of run-off (approximately $6 \mathrm{ml}$ per plant), for both greenhouse experiments. In the first greenhouse experiment, three foliar Si rates were tested: 500, 1,000, and 2,000 mg kg-1 $(\mathrm{pH}$ $10,10.1$, and 10.4 , respectively). In the second greenhouse experiment, only the Si rate of $2,000 \mathrm{mg} \mathrm{kg}^{-1}$ rate was tested. The manufacturer-recommended $\mathrm{Si}$ rate for foliar sprays is $1,000 \mathrm{mg} \mathrm{kg}^{-1}$.

The foliar Si treatment solutions were applied twice in the first greenhouse experiment, at 38 and 48 DAP. These ages corresponded to soybean physiological stages V6 (sixth trifoliate fully expanded) and R2 (full bloom, flower at top two nodes). In the second greenhouse experiment, the foliar $\mathrm{Si}$ treatment solutions were applied three times at 18,23 , and 28 DAP. This corresponded to physiological stages V3 (third trifoliate fully expanded), V5 (fifth trifoliate fully expanded), and V6 (sixth trifoliate fully expanded). A foliar control treatment consisted of DI water with $\mathrm{pH}$ adjusted to 10.4 with $\mathrm{KOH}$. This was to control for a possible $\mathrm{pH}$ effect (equivalent to the foliar solution $\mathrm{pH}$ for $\mathrm{Si}$ at $2,000 \mathrm{mg} \mathrm{kg}^{-1}$ ). A control solution of DI water ( $\mathrm{Si}$ at $0 \mathrm{mg} \mathrm{kg}^{-1}, \mathrm{pH}$ 7.2) was used in both greenhouse experiments as a control for the spraying effect (i.e., spraying action may possibly wash urediniospores off of the leaf surfaces).

In the second greenhouse experiment, a combined treatment of soil-applied Si at $1.92 \mathrm{t} \mathrm{ha}^{-1}$ plus a foliar Si treatment at $2,000 \mathrm{mg}$ $\mathrm{kg}^{-1}$ was included to test for potential additive effects (foliar- and soil-applied $\mathrm{Si}$ ).

Field experiment. Repeated field experiments were conducted during 2007 and 2008 at the North Florida Research and Education Center in Quincy. The average monthly temperature for July, August, and September, when SBR disease evaluations were made, ranged from 24 to $27^{\circ} \mathrm{C}$ for both years (11), which is considered suitable for SBR development $(21,27,28)$. Both soybean cultivars (DP5634RR and Hinson Long Juvenile) were tested. The study area used in the 2007 field experiment was comprised of two related soil series, with $60 \%$ of the area being a Tifton fine loam (fine-loamy, kaolinitic, thermic Plinthic Kandiudult) and $40 \%$ being a Norfolk fine loam (fine-loamy, kaolinitic, thermic Typic Kandiudult) (48). The primary difference between series was that Tifton had plinthite in the B horizon. The experimental area used in the 2008 experiment was a Norfolk series soil (48). In both years, the field experiment received standard commercial soybean cultural practices for soybean planted for hay or silage (50). Seeding rate was adjusted based on pure live seed, which was determined to be about 30 seeds $\mathrm{m}^{-1}$. Each experimental unit $(22.2$ $\mathrm{m}^{2}$ ) was comprised of four $6.1-\mathrm{m}$ rows with $0.91 \mathrm{~m}$ between rows. Alleys $(1.8 \mathrm{~m})$ separated each experimental unit.

The soil Si treatments (Vansil W-50) were manually applied and raked into the upper $5 \mathrm{~cm}$ of soil within field plots with W-50 at 0 , $4.44,8.88$, and $17.76 \mathrm{~kg} \mathrm{plot}^{-1}\left(\mathrm{~W}-50\right.$ at $0,2,4$, and $8 \mathrm{t} \mathrm{ha}^{-1}$ or Si at $0,0.48,0.96$, and $1.92 \mathrm{t} \mathrm{ha}^{-1}$ ) 1 day prior to sowing in 2007 and 6 days prior to sowing in 2008 . The $\mathrm{Ca}(\mathrm{OH})_{2}$ control treatment was equivalent to lime at $17.76 \mathrm{~kg} \mathrm{plot}^{-1}\left(\mathrm{Ca}(\mathrm{OH})_{2}\right.$ at $8 \mathrm{t} \mathrm{ha}^{-1}$ or $\mathrm{Ca}$ at $\left.4.3 \mathrm{t} \mathrm{ha}^{-1}\right)$. To apply the foliar treatments $\left(\mathrm{K}_{2} \mathrm{SiO}_{3}\right.$ solutions with $\mathrm{Si}$ at $500,1,000$, or $2,000 \mathrm{mg} \mathrm{kg}^{-1}$ ), a backpack sprayer (D. B. Smith Field King, Mills, NY) was used. The center two rows of each plot were sprayed until leaf runoff at 1.1 liter plot $^{-1}$, which was proportional to 1,000 liters $\mathrm{ha}^{-1}$. A DI $\mathrm{H}_{2} \mathrm{O}\left(\mathrm{Si}\right.$ at $\left.0 \mathrm{mg} \mathrm{kg}^{-1}\right)$ and $\mathrm{pH}-\mathrm{ad}-$ justed water (10.4 with $\mathrm{KOH})$ controls were also tested. All foliar treatments were applied three times, at 39, 53, and 67 DAP for 2007 and at 29, 42, and 53 DAP for 2008. This corresponded to physiological stages V5 (fully expanded fifth trifoliate), R2 (full bloom), and R3 (beginning pod). 
Inoculum procedures. Greenhouse experiments. The procedures to obtain the urediniospore suspensions were the same for both greenhouse and field experiments. Urediniospores of $P$. pachyrhizi were collected from greenhouse plants, using leaves with approximately $35 \%$ disease as the inoculum source (15). Excised leaves were gently washed with deionized water and blotted dry with absorbent paper towel. Subsequently, the leaves were placed in a sealed transparent plastic box containing Whatman no. 1 filter paper (Whatman. Piscataway, NJ) saturated with DI water. Following a 48 -h incubation at $23^{\circ} \mathrm{C}$, fresh urediniospores were collected with a brush and placed into a $0.05 \%$ surfactant solution (Tween-20; Sigma-Aldrich, St. Louis). A hemacytometer was used to adjust the resulting urediniospore suspension $\left(1 \times 10^{4}\right.$ cells ml $^{-1}$ for the first greenhouse study and $3 \times 10^{4}$ cells $\mathrm{ml}^{-1}$ for the second greenhouse study).

The soybean plants were inoculated on the day after the first foliar Si application, which was 39 and 19 DAP for the first and second greenhouse experiments, respectively. The urediniospore suspensions were sprayed using an atomizer containing a propellant cartridge (Sprã-tool; Aervoe Industries Inc.). Each plant was sprayed on both leaf surfaces until run-off (approximately $6 \mathrm{ml}$ per plant). The pots with the inoculated plants were sealed in 50-liter white plastic bags (Glad Tall Kitchen Bag, Oakland, CA) for $24 \mathrm{~h}$. The first greenhouse experiment received a second application of urediniospore suspension $\left(1 \times 10^{4}\right.$ cells ml $\left.{ }^{-1}\right) 9$ days after the first inoculation because no infection symptoms were observed as of that date.

Field experiment. Due to low rainfall (which inhibits natural SBR infection) in the 2007 field experiment, the middle rows of each experimental unit were artificially inoculated $\left(3 \times 10^{3}\right.$ cells $\mathrm{ml}^{-1}$ ) in the evening at 47 DAP with a backpack sprayer (D. B. Smith Field King). The center two rows of each experimental unit were sprayed with the inoculum suspension until leaf runoff at 1.1 liter plot $^{-1}$, which was proportional to 1,000 liters $\mathrm{ha}^{-1}$. Artificial inoculations were not needed in the 2008 experiment year because environmental conditions were conducive to SBR disease infection.

Disease ratings. Disease severity ratings were recorded based on the Horsfall-Barrett scale (15). In all, 7 SBR disease evaluations were made from 12 through 31 August in the first greenhouse experiment and 15 disease evaluations were made from 28 June through 12 July in the second greenhouse experiment. In the field experiment, the two center rows of each experimental unit were used for SBR disease evaluation, thereby avoiding border effects. In all, 5 SBR disease evaluations were conducted from 8 September through 6 October 2007 and 17 disease evaluations were conducted from 13 August through 16 September 2008. Midpoint values of the disease rating scale were used to plot disease progress curves. The area under the disease progress curve (AUDPC) used to determine treatment effectiveness (17) was calculated as:

$$
\text { AUDPC }=\sum_{i=1}^{n-1}\left[\left(y_{i}+y_{i+1}\right) \div 2\right]\left(t_{i+1}-t_{i}\right)
$$

where $y_{i}=$ disease proportion (percentage severity) at the $i$ th observation, $t_{i}=$ time (days), and $n=$ total number of observations (47).

Plant and soil sampling. All soybean leaves from each pot were collected at 69 and 34 DAP for the first and second greenhouse experiments, respectively. They were gently rinsed with distilled water for approximately $10 \mathrm{~s}$ and oven dried at $70^{\circ} \mathrm{C}$ for $48 \mathrm{~h}$. In the repeated field experiment at soybean development stage R7 (80 and 101 DAP for DP5634RR and Hinson Long Juvenile cultivars, respectively, in 2007 and 84 and 98 DAP for DP5634RR and Hinson Long Juvenile, respectively, in 2008), six plants were randomly removed from each experimental unit and all leaves were used for Si analysis. Oven-dried leaf samples from both greenhouse and field experiments were ground separately and sieved through a $2-\mathrm{mm}^{2}$ stainless steel screen. Leaf Si concentration was determined following the methodology described by Elliott and Sny$\operatorname{der}(9)$, with subsequent automated colorimetric analysis at $670 \mathrm{~nm}$.
At the conclusion of each experiment, air-dried soil samples of all treatments from the greenhouse studies and soil $(0$ to $15 \mathrm{~cm}$ depth) from the field experiment were analyzed for soil water $\mathrm{pH}$ $(1: 2, \mathrm{vol} / \mathrm{vol})$ and soil-extractable $\mathrm{Ca}, \mathrm{Mg}$, and $\mathrm{Si}$ concentrations using a $0.5 \mathrm{~N}$ acetic acid extraction method (43) at the University of Florida, Belle Glade EREC soil test laboratory.

Statistical analyses. The first greenhouse experiment was a two-by-nine factorial design with two soybean cultivars, nine $\mathrm{Si}$ treatments, and three replications $(n=54)$, while the second greenhouse experiment was a randomized complete block design with seven Si treatments and four replications $(n=28)$. The field experiment was a $2 \times 10$ factorial design with two soybean cultivars, 10 Si treatments, and four replications $(n=80)$, repeated in the second year. Analysis of variance was used to determine significant treatment effects (SAS for Windows, version 9.1; SAS Institute, Cary, NC). Treatment means were compared $(P \leq 0.05)$ using Fisher's protected least significant difference. SigmaPlot (version 10.0; Hearne Scientific Software, San Rafael, CA) was used to plot disease severity over time.

\section{Results}

Soil and tissue composition. The soil and leaf Si concentrations from the first greenhouse experiment are given in Figure 1. The soil $\mathrm{Si}$ values were similar among soybean cultivars. The soil $\mathrm{Si}$ concentration from the $\mathrm{Si}$ at $1.92 \mathrm{t} \mathrm{ha}^{-1}$ treatment was $63 \%$ greater than the $0.96 \mathrm{t} \mathrm{ha}^{-1}$ treatment and $673 \%$ greater than the control (Fig. 1A). The average leaf Si concentration of cv. DP5634RR was about $45 \%$ greater than for cv. Hinson Long Juvenile in the first greenhouse experiment (Fig. 1B). Regardless of cultivar, the average leaf Si concentration of the Si at $1.92 \mathrm{t} \mathrm{ha}^{-1}$ treatment was $29 \%$ greater than the $0.96 \mathrm{t} \mathrm{ha}^{-1}$ treatment and $277 \%$ greater than the control treatment (Fig. 1B). Leaf Si concentrations from the foliar $\mathrm{Si}$ treatments ( $\mathrm{Si}$ at 500, 1,000, and $2,000 \mathrm{mg} \mathrm{kg}{ }^{-1}$ ) were not significantly different from each other but were about 33\% signifi-

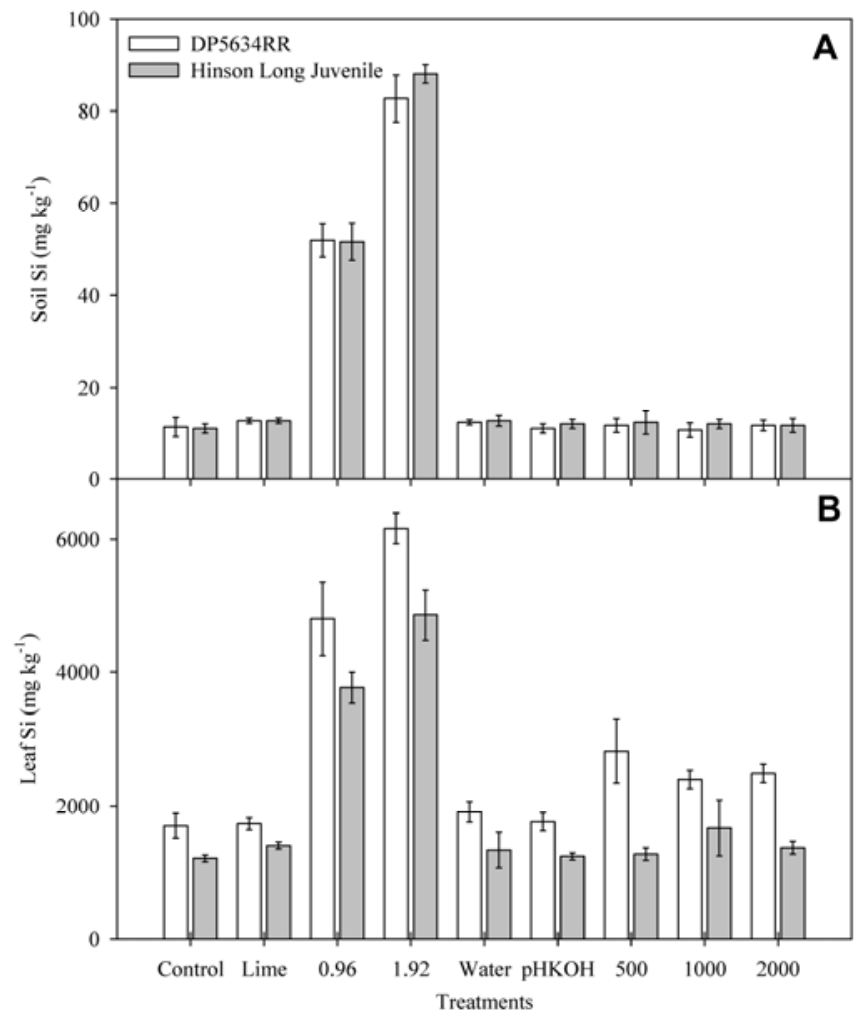

Fig. 1. A, Soil silicon (Si) concentration and B, leaf Si concentration at 69 days after planting for cvs. DP5634RR and Hinson Long Juvenile in the first greenhouse experiment. Vertical bars $=$ standard deviation of the mean. Soil treatments: Control $\left(\mathrm{Si}\right.$ at $\left.0 \mathrm{tha}^{-1}\right)$, Lime $\left(8 \mathrm{t} \mathrm{ha}^{-1}\right), 0.96\left(\mathrm{Si}\right.$ at $\left.0.96 \mathrm{t} \mathrm{ha}^{-1}\right)$, and $1.92\left(\mathrm{Si}\right.$ at $\left.1.92 \mathrm{t} \mathrm{ha}^{-1}\right)$; foliar treatments: Water ( $\mathrm{Si}$ at $0 \mathrm{mg} \mathrm{kg}^{-1}$ ), pHKOH (pH adjusted with $\left.\mathrm{KOH}\right), 500$ ( $\mathrm{Si}$ at $500 \mathrm{mg} \mathrm{kg}^{-1}$ ), 1000 (Si at 1,000 $\mathrm{mg} \mathrm{kg}^{-1}$ ), and 2000 (Si at 2,000 $\mathrm{mg} \mathrm{kg}^{-1}$ ). 
cantly greater than the foliar controls receiving either water or $\mathrm{pH}$ adjusted water (Fig. 1B).

The soil and leaf Si concentrations from the second greenhouse experiment are given in Figure 2. The soil Si concentrations of treatments containing $\mathrm{Si}$ at $1.92 \mathrm{tha}^{-1}$ and $1.92 \mathrm{t} \mathrm{ha}^{-1}+\mathrm{Si}$ at 2,000 $\mathrm{mg} \mathrm{kg}^{-1}$ were not significantly different from each other (Fig. 2A). The average soil Si concentration of the $\mathrm{Si}$ at $1.92 \mathrm{t} \mathrm{ha}^{-1}$ and $1.92 \mathrm{t}$ $\mathrm{ha}^{-1}+\mathrm{Si}$ at $2,000 \mathrm{mg} \mathrm{kg}^{-1}$ treatments were $387 \%$ greater than the control treatment. The average leaf Si concentration of the combined $\left(\mathrm{Si}\right.$ at $1.92 \mathrm{t} \mathrm{ha}^{-1}+\mathrm{Si}$ at $2,000 \mathrm{mg} \mathrm{kg}^{-1}$ ) treatment was $43 \%$ greater than the $2,000 \mathrm{mg} \mathrm{kg}^{-1}$ foliar treatment and $76 \%$ greater than the $1.92 \mathrm{t} \mathrm{ha}^{-1}$ treatment (Fig. 2B). No significant differences were observed among the various $\mathrm{Si}$ control treatments $(\mathrm{Si}$ at $0 \mathrm{t}$ $\mathrm{ha}^{-1}$, lime at $8 \mathrm{tha}^{-1}$, Si at $0 \mathrm{mg} \mathrm{kg}^{-1}$, and $\mathrm{KOH} \mathrm{pH}$-adjusted water foliar treatment).

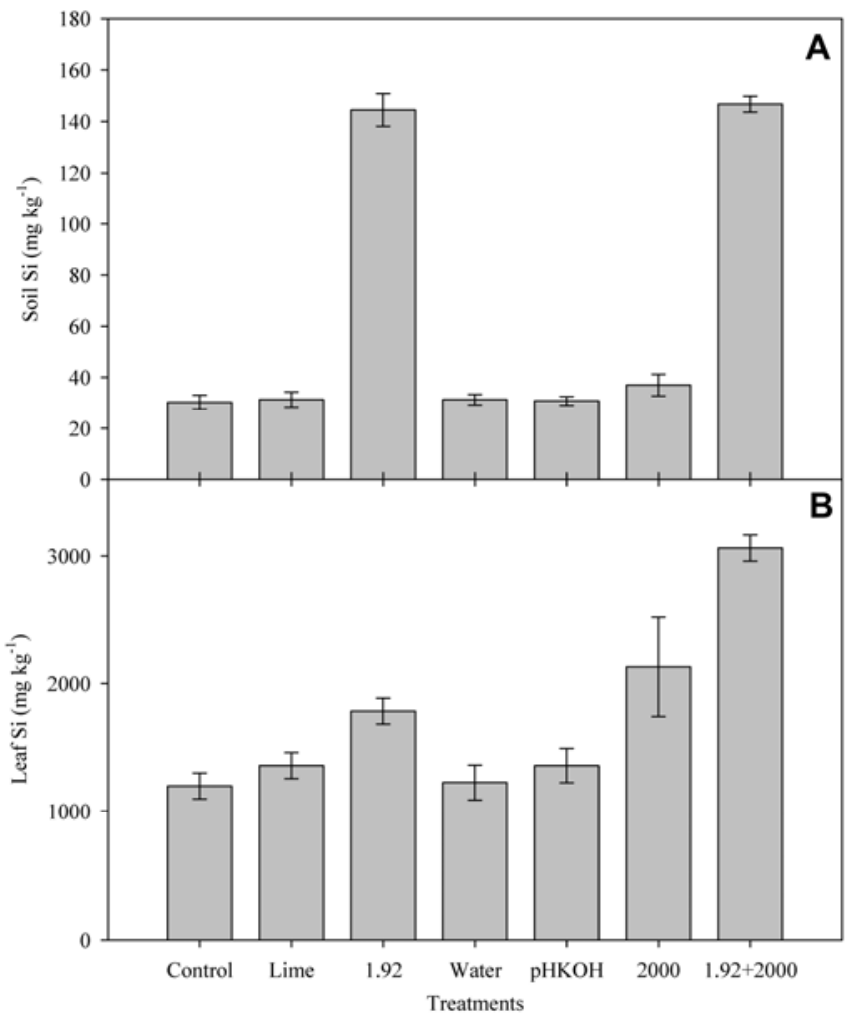

Fig. 2. A, Soil silicon (Si) concentration and B, leaf Si concentration at 34 days after planting in the second greenhouse experiment. Vertical bars = standard deviation of the mean. Soil treatments: Control (Si at $\left.0 \mathrm{t} \mathrm{ha}^{-1}\right)$, Lime $\left(8 \mathrm{tha}^{-1}\right)$, and 1.92 (Si at $1.92 \mathrm{t}$ $\mathrm{ha}^{-1}$ ); foliar treatments: Water (Si at $0 \mathrm{mg} \mathrm{kg}^{-1}$ ), $\mathrm{pHKOH}$ (pH adjusted with $\mathrm{KOH}$ ), 2000 (Si at 2,000 $\mathrm{mg} \mathrm{kg}^{-1}$ ), and 1.92+2000 (Si at $1.92 \mathrm{t} \mathrm{ha}^{-1}+2,000 \mathrm{mg} \mathrm{kg}^{-1}$ foliar).
Soil $\mathrm{pH}$ and $0.5 \mathrm{~N} \mathrm{HOAc-extractable} \mathrm{Si}, \mathrm{Ca}$, and $\mathrm{Mg}$ from the repeated field experiments are presented in Table 2. The soil $\mathrm{pH}$ from both years usually increased as the soil Si rate increased. No significant differences were observed between the soil control ( $\mathrm{Si}$ at $0 \mathrm{tha}^{-1}$ ) and the foliar Si treatments. Also, the soil $\mathrm{pH}$ from the $\mathrm{Ca}(\mathrm{OH})_{2}$ control treatment was comparable with the soil $\mathrm{pH}$ of $\mathrm{Si}$ at $1.92 \mathrm{t} \mathrm{ha}^{-1}$. In both years, Si-amended soil treatments had greater extractable soil Si than nonamended soil treatments. Silicon at $1.92 \mathrm{t}$ $\mathrm{ha}^{-1}$ was 363 and $464 \%$ greater than the control (St at $0 \mathrm{t} \mathrm{ha}^{-1}$ ) for 2007 and 2008, respectively. There were no significant differences between the control soil Si concentration and the five foliar treatments ( $\mathrm{pH} \mathrm{KOH}$-adjusted solution and $\mathrm{Si}$ at $0,500,1,000$, and 2,000 $\mathrm{mg} \mathrm{kg}^{-1}$ ) for either year.

Final soil Ca concentration from the lime $\left(8 \mathrm{t} \mathrm{ha}^{-1}\right)$ and $\mathrm{Si}$ at 0.96 and $1.92 \mathrm{t} \mathrm{ha}^{-1}$ treatments were 62,25 , and $35 \%$ greater than the control treatment for 2007, and 595, 71, and $253 \%$ greater than the control treatment for 2008. The soil Ca concentration from the $\mathrm{Si}$ at $0.48 \mathrm{t} \mathrm{ha}^{-1}$ treatment was not significantly different from the control treatment in either year (Table 2). The greater soil Ca concentration from 2007 might be due to residual $\mathrm{Ca}$ from past land management at this field site. Soil $\mathrm{Mg}$ concentrations increased with treatments receiving lime, which were 133 and $31 \%$ greater than the control treatment for 2007 and 2008, respectively. There was a trend of increasing soil $\mathrm{Mg}$ with increasing wollastonite application but it was not significant (Table 2). Wollastonite contains about $1.5 \% \mathrm{MgO}$.

Leaf $\mathrm{Si}$ concentration from the field studies are found in Figure 3. The average leaf Si concentration for cv. Hinson Long Juvenile was $56 \%$ greater than for cv. DP5634RR in both years. Leaf Si concentrations from the highest soil application rate $(\mathrm{Si}$ at $1.92 \mathrm{t}$ $\mathrm{ha}^{-1}$ ) and the highest foliar rate ( $\mathrm{Si}$ at $2,000 \mathrm{mg} \mathrm{kg}^{-1}$ ) were comparable, while the moderate soil rate $\left(\mathrm{Si}\right.$ at $0.96 \mathrm{tha}^{-1}$ ) resulted in leaf Si similar to that in the low and moderate foliar rates ( $\mathrm{Si}$ at 500 and $1,000 \mathrm{mg} \mathrm{kg}^{-1}$; Fig. 3). In comparison, the average leaf $\mathrm{Si}$ from the $\mathrm{Si}$ at $0.48 \mathrm{t} \mathrm{ha}^{-1}$ soil rate was the lowest among all $\mathrm{Si}$ application rates. No significant differences were observed in leaf Si concentration among the non-Si treatments.

SBR disease progression. Disease onset was delayed an average of 3 days for soil treatment receiving $\mathrm{Si}$ at $1.92 \mathrm{t} \mathrm{ha}^{-1}$ in both greenhouse and field experiments and for the foliar Si treatment ( $\mathrm{Si}$ at 2,000 mg kg-1 ) of the second greenhouse experiment (Table 3). The delay in disease onset of SBR is presented for only the second of the two greenhouse experiments in Figure 4. The foliar Si treatments were less effective in delaying disease onset under field conditions. In the repeated field experiment, the average 3-day delay for disease onset was clearly evident when $\mathrm{Si}$ was supplied via soil (Fig. 5B and E).

The AUDPCs from the greenhouse experiments are presented in Table 3, and the AUDPCs from the field experiments are presented in Table 4. In the first greenhouse experiment, the AUDPCs from

Table 2. Final soil $\mathrm{pH}$ and $0.5 \mathrm{~N}$ HOAc-extractable $\mathrm{Si}, \mathrm{Ca}$, and $\mathrm{Mg}\left(\mathrm{mg} \mathrm{kg}^{-1}\right)$ at 80 and 84 days after planting for 2007 and 2008 field experiments, respectively ${ }^{z}$

\begin{tabular}{|c|c|c|c|c|c|c|c|c|}
\hline \multirow[b]{2}{*}{ Treatments } & \multicolumn{4}{|c|}{2007} & \multicolumn{4}{|c|}{2008} \\
\hline & $\mathbf{S i}$ & Soil pH & $\mathbf{C a}$ & Mg & $\mathbf{S i}$ & Soil pH & $\mathbf{C a}$ & Mg \\
\hline \multicolumn{9}{|l|}{ Soil Si (t ha $\left.{ }^{-1}\right)$} \\
\hline Lime $\left(8 \mathrm{tha}^{-1}\right)$ & $31 \mathrm{~d}$ & $7.3 \mathrm{ab}$ & $2,236 \mathrm{a}$ & $293 \mathrm{a}$ & $49 \mathrm{~d}$ & $8.2 \mathrm{a}$ & $2,046 \mathrm{a}$ & $131 \mathrm{a}$ \\
\hline 0 & $32 \mathrm{~d}$ & $6.8 \mathrm{cde}$ & $1,382 \mathrm{~d}$ & $126 \mathrm{~cd}$ & $25 \mathrm{e}$ & $6.6 \mathrm{e}$ & $295 \mathrm{~d}$ & $100 \mathrm{bc}$ \\
\hline 0.48 & $48 \mathrm{c}$ & $6.6 \mathrm{e}$ & $1,377 \mathrm{~d}$ & $126 \mathrm{~cd}$ & $75 \mathrm{c}$ & $7.2 \mathrm{~d}$ & $503 \mathrm{~cd}$ & $96 \mathrm{c}$ \\
\hline 0.96 & $99 \mathrm{~b}$ & $7.2 \mathrm{ab}$ & $1,733 \mathrm{bc}$ & $130 \mathrm{~cd}$ & $120 \mathrm{~b}$ & $7.6 \mathrm{c}$ & $740 \mathrm{c}$ & $102 b c$ \\
\hline 1.92 & $148 \mathrm{a}$ & $7.5 \mathrm{a}$ & $1,874 \mathrm{~b}$ & $135 \mathrm{bcd}$ & $141 \mathrm{a}$ & $7.9 \mathrm{~b}$ & $1,040 \mathrm{~b}$ & $120 \mathrm{ab}$ \\
\hline \multicolumn{9}{|l|}{ Foliar Si $\left(\mathrm{mg} \mathrm{kg}^{-1}\right)$} \\
\hline $\mathrm{KOH}(\mathrm{pH} 10.4)$ & $30 \mathrm{~d}$ & $6.7 \mathrm{de}$ & $1,398 \mathrm{~d}$ & $124 \mathrm{~d}$ & $22 \mathrm{e}$ & $6.5 \mathrm{e}$ & $349 \mathrm{~d}$ & $98 \mathrm{bc}$ \\
\hline 0 (DI water) & $34 \mathrm{~d}$ & $6.8 \mathrm{cde}$ & $1,534 \mathrm{~cd}$ & $136 \mathrm{bcd}$ & $22 \mathrm{e}$ & $6.5 \mathrm{e}$ & $339 \mathrm{~d}$ & $99 \mathrm{bc}$ \\
\hline 500 & $32 \mathrm{~d}$ & $6.9 \mathrm{~cd}$ & $1,527 \mathrm{~cd}$ & $138 \mathrm{bcd}$ & $24 \mathrm{e}$ & $6.5 \mathrm{e}$ & $312 \mathrm{~d}$ & $100 \mathrm{bc}$ \\
\hline 1,000 & $33 \mathrm{~d}$ & $7.0 \mathrm{bc}$ & $1,675 \mathrm{bc}$ & $148 \mathrm{bc}$ & $26 \mathrm{e}$ & $6.6 \mathrm{e}$ & $357 \mathrm{~cd}$ & $113 a b c$ \\
\hline 2,000 & $35 \mathrm{~d}$ & $7.0 \mathrm{bc}$ & $1,747 \mathrm{ab}$ & $154 \mathrm{~b}$ & $25 \mathrm{e}$ & $6.6 \mathrm{e}$ & $254 \mathrm{~d}$ & $99 \mathrm{bc}$ \\
\hline
\end{tabular}

${ }^{z}$ Values sharing the same letter, within the same column, did not differ significantly at $P \leq 0.05$ as determined by the Fisher's protected least significant difference test. 
treatments that included $\mathrm{Si}$ amendments ( $\mathrm{Si}$ at 0.96 and $1.92 \mathrm{t} \mathrm{ha}^{-1}$ and $500,1,000$, and $2,000 \mathrm{mg} \mathrm{kg}^{-1}$ ) were not significantly different from one another, but all were $89 \%$ lower than the Si at $0 \mathrm{t} \mathrm{ha}^{-1}$ soil control (Table 3).

The second greenhouse experiment resulted in greater AUDPC values (Table 3). In the first greenhouse experiment, the soybean plants were inoculated at 39 DAP compared with 19 DAP in the second experiment which, together with the three times greater $(3$ $\times 10^{4}$ cells $\mathrm{ml}^{-1}$ ) urediniospore suspension applied to plants in the second greenhouse experiment, were probably the major factors contributing to the AUDPC value differences observed between the two experiments. Although no significant AUDPC differences were observed among the $\mathrm{Si}$ at $1.92 \mathrm{t} \mathrm{ha}^{-1}, 2,000 \mathrm{mg} \mathrm{kg}^{-1}$, and combined treatments $\left(1.92 \mathrm{t} \mathrm{ha}^{-1}+2,000 \mathrm{mg} \mathrm{kg}^{-1}\right)$ for the second greenhouse experiment, their AUDPC values were 55\% lower when compared with control plants (i.e., $\mathrm{Si}$ at $0 \mathrm{tha}^{-1}$, lime at $8 \mathrm{tha}^{-1}$, Si at $0 \mathrm{mg}$ $\mathrm{kg}^{-1}$ foliar, and $\mathrm{pH} \mathrm{KOH}$ ).

In field studies, the $\mathrm{Si}$ at $1.92 \mathrm{t} \mathrm{ha}^{-1}$ soil treatment and 2,000 mg $\mathrm{kg}^{-1}$ foliar treatment resulted in the lowest AUDPC values among all treatments (Table 4), while the non-Si controls, particularly foliar water treatments, resulted in the highest AUDPC values. Although not as obvious as in 2007, the data from 2008 suggested that, as $\mathrm{Si}$ application rates increased, final AUDPC values decreased (Table 4).

\section{Discussion}

SBR disease development. This is the first known reported study that compared foliar- and soil-applied Si concurrently on SBR development under greenhouse and field conditions. High leaf Si concentrations compared with the control were constantly associated with reduced SBR development across all experiments, as shown by the lower AUDPCs with those treatments (Tables 3 and 4). The time delay for SBR onset with soil Si treatments, in conjunction with the greater AUDPCs of the non-Si treatments, suggested that $\mathrm{Si}$ may have affected urediniospore direct leaf penetration and consequently, slowed SBR development, especially at the initial stages of the epidemic $(7,29)$. The effects of $\mathrm{Si}$ treatments on AUDPC of SBR showed that Si applications in the

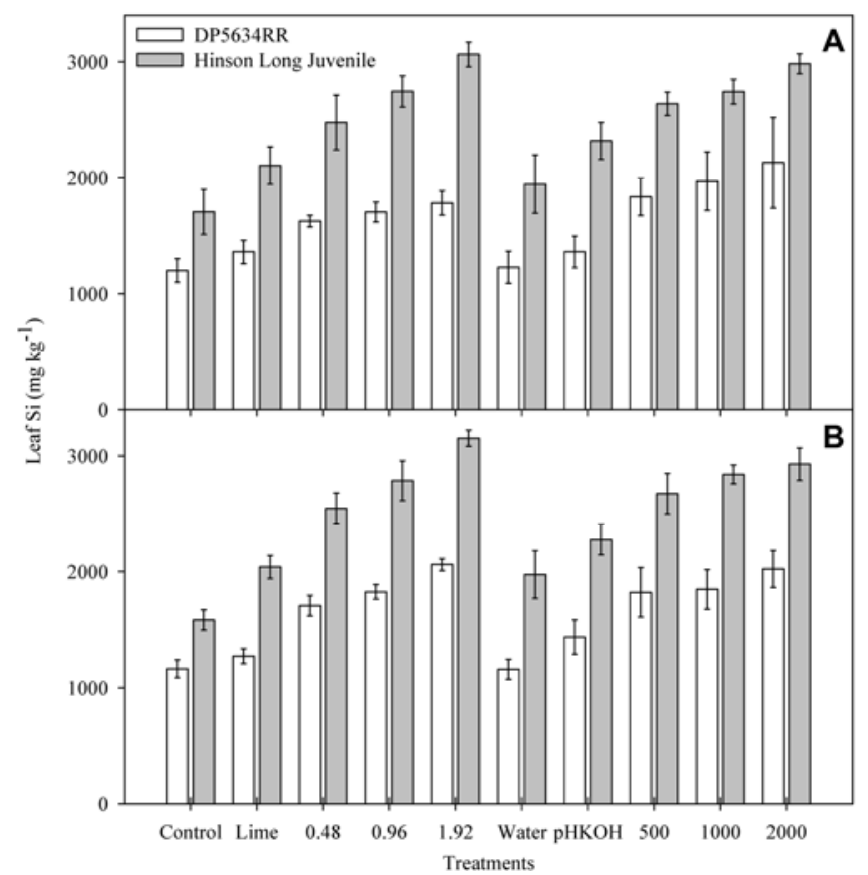

Fig. 3. Leaf silicon (Si) concentrations of A, 2007 and B, 2008 field experiments at the R7 (beginning maturity) soybean physiological stage. Vertical bars = standard deviation of the mean. Soil treatments: Control (Si at $\left.0 \mathrm{tha}^{-1}\right)$, Lime $\left(8 \mathrm{t} \mathrm{ha}^{-1}\right), 0.48$ (Si at $\left.0.48 \mathrm{tha}^{-1}\right), 0.96\left(\mathrm{Si}\right.$ at $\left.0.96 \mathrm{t} \mathrm{ha}^{-1}\right)$, and $1.92\left(\mathrm{Si}\right.$ at $\left.1.92 \mathrm{t} \mathrm{ha}^{-1}\right)$; foliar treatments: Water ( $\mathrm{Si}$ at $0 \mathrm{mg} \mathrm{kg}^{-1}$ ), pHKOH (pH adjusted with $\mathrm{KOH}$ ), 500 (Si at 500 $\mathrm{mg} \mathrm{kg}^{-1}$ ), 1000 (Si at 1,000 $\mathrm{mg} \mathrm{kg}^{-1}$ ), and 2000 (Si at $2,000 \mathrm{mg} \mathrm{kg}^{-1}$ ). greenhouse experiments, whether soil or foliar, were not significantly different, regardless of $\mathrm{Si}$ application rates, and all AUDPC values were significantly lower than the AUDPC values from non-Si treatments. It is possible that disease pressure under greenhouse conditions was not as severe as in the field and, therefore, even low Si rates were effective against SBR.

Under field conditions, the results suggested that Si soil amendments were more effective than foliar-applied Si for suppressing SBR development because the soil treatments resulted in both a

Table 3. Integrated area under disease progress curve (AUDPC) for soybean rust from the greenhouse experiments ${ }^{\mathrm{z}}$

\begin{tabular}{llc}
\hline & \multicolumn{2}{c}{ AUDPC per experiment } \\
\cline { 2 - 3 } Treatments & First & Second \\
\hline Control $\left(\mathrm{Si}_{\left.\text {at } 0 \mathrm{t} \mathrm{ha}^{-1}\right)}\right.$ & $49.3 \mathrm{ab}$ & $86.6 \mathrm{a}$ \\
Lime $\left(8 \mathrm{t} \mathrm{ha}^{-1}\right)$ & $53.3 \mathrm{a}$ & $85.4 \mathrm{a}$ \\
$\mathrm{Si}$ at $0.96 \mathrm{t} \mathrm{ha}^{-1}$ & $25.3 \mathrm{~cd}$ & $\mathrm{NA}$ \\
$\mathrm{Si}$ at $1.92 \mathrm{t} \mathrm{ha}^{-1}$ & $22.8 \mathrm{~cd}$ & $55.4 \mathrm{~b}$ \\
$\mathrm{KOH}\left(\mathrm{pH} \mathrm{l0.4}^{-10}\right)$ & $50.8 \mathrm{ab}$ & $85.4 \mathrm{a}$ \\
$\mathrm{Si}$ at $0 \mathrm{mg} \mathrm{kg}^{-1}$ & $36.6 \mathrm{bc}$ & $83.1 \mathrm{a}$ \\
$\mathrm{Si}$ at $500 \mathrm{mg} \mathrm{kg}^{-1}$ & $32.9 \mathrm{~cd}$ & $\mathrm{NA}$ \\
Si at $1,000 \mathrm{mg} \mathrm{kg}^{-1}$ & $31.1 \mathrm{~cd}$ & $\mathrm{NA}$ \\
Si at $2,000 \mathrm{mg} \mathrm{kg}^{-1}$ & $18.5 \mathrm{~d}$ & $58.1 \mathrm{~b}$ \\
Si at $1.92 \mathrm{t} \mathrm{ha}^{-1}+2,000 \mathrm{mg} \mathrm{kg}^{-1}$ & $\mathrm{NA}$ & $54.4 \mathrm{~b}$ \\
\hline
\end{tabular}

${ }^{z}$ Values sharing the same letter, within the same experiment, did not differ significantly at $P \leq 0.05$ as determined by the Fisher's protected least significant difference test. $\mathrm{NA}=$ not applicable. $\mathrm{Si}$ in $\mathrm{tha}^{-1}$ is soil applied, Si in $\mathrm{mg} \mathrm{kg}^{-1}$ is foliar applied.

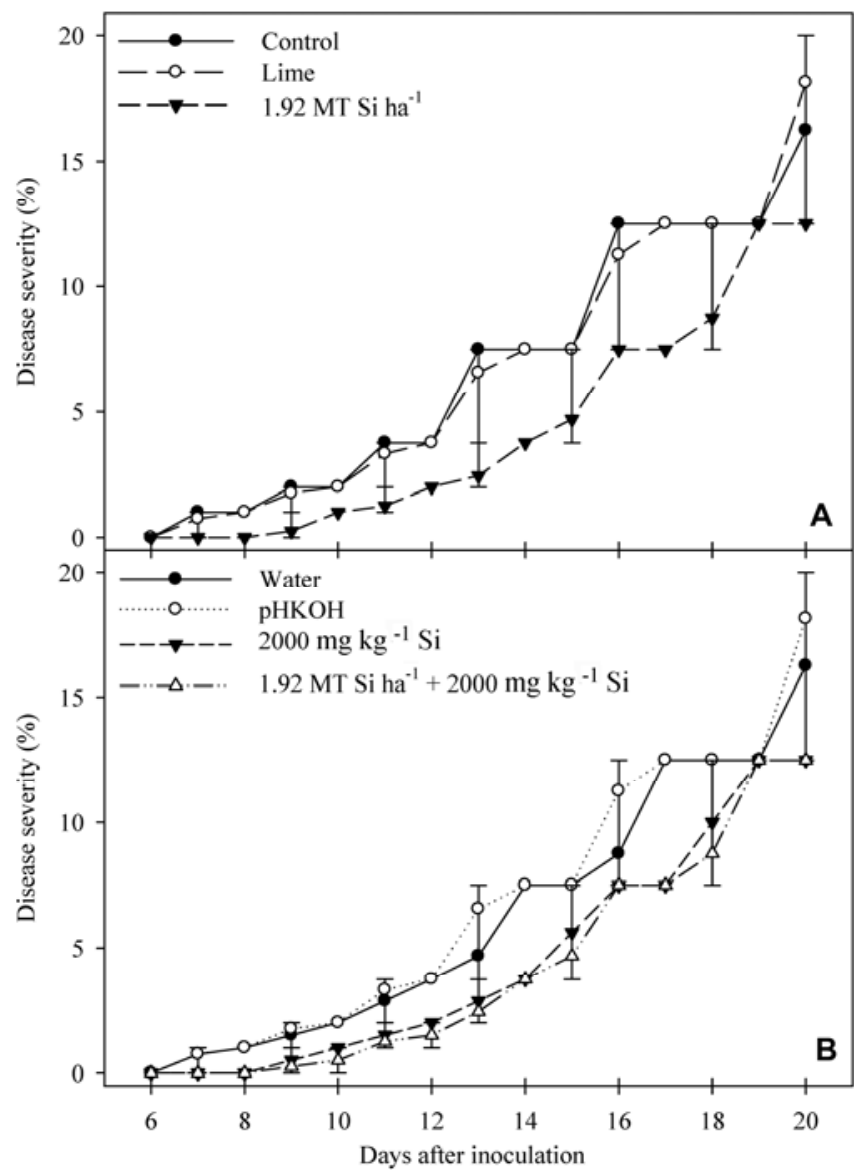

Fig. 4. Greenhouse experiment 2 disease progress of soybean rust treated with soil applied wollastonite - $\mathbf{A}$, silicon (Si) at $1.92 \mathrm{tha}^{-1}$ or $\mathbf{B}$, potassium silicate at $\mathrm{Si}$ at $2,000 \mathrm{mg} \mathrm{kg}^{-1}$ foliar and the combined treatment ( $\mathrm{Si}$ at $1.92 \mathrm{t} \mathrm{ha}^{-1}$ soil-applied + $2,000 \mathrm{mg} \mathrm{kg}^{-1}$ foliar) as compared with the controls: Control (no Si), Lime ( $\left.8 \mathrm{t} \mathrm{ha}^{-1}\right)$, Water, and $\mathrm{pHKOH}$ (pH adjusted with $\mathrm{KOH}$ ) treatments. Vertical bars = standard deviation from the mean. Foliar Si treatments were applied the day before urediniospore inoculation and at 4 and 9 days after inoculation. 
delay in disease onset and a reduction in AUDPC. The overall low AUDPC values observed in 2007 were probably due to unusually dry weather conditions that occurred that year. Nolla et al. (33) tested different soil Si rates to determine whether Si could suppress a number of soybean diseases, including SBR. Although they observed suppression to frogeye leaf spot and downy mildew, they observed no effect against SBR. Unlike the current study, the authors evaluated the effects of their Si treatments one time, 79 DAP, hence missing any potential delay in disease onset as well as reduction in disease over time.

The lime $\left(8 \mathrm{t} \mathrm{ha}^{-1}\right)$ control and the $\mathrm{pH}$-adjusted water control foliar treatments were intended to discriminate $\mathrm{pH}$ effects from $\mathrm{Si}$ effects in SBR control across all experiments. The AUDPCs for these treatments were significantly greater than the AUDPCs for soil and foliar Si treatments (Tables 3 and 4), indicating that neither $\mathrm{Ca}$ or $\mathrm{pH}$ was a possible contributing factor in SBR development. Comparatively, the $\mathrm{Si}$ at $0 \mathrm{mg} \mathrm{kg}^{-1}$ foliar treatment was designated to mimic washing leaves of urediniospores caused by the foliar treatment applications.

Soil versus foliar Si treatments. The mechanisms responsible for the delay of SBR onset may include a Si physical barrier, similar to the double $\mathrm{Si}$ layer reported beneath the cuticle of $\mathrm{Si}$ amended rice leaves and sheaths (51), or an expression of pathogenesis-induced host defense responses (physiological barrier; 7). The subcuticular Si layer appears to be more prominent when plants absorb $\mathrm{Si}$ by the roots than from a foliar application $(12,24,39)$, because foliar Si absorption is likely very low, if at all. Guével et al. (12) also found that foliar Si applications were not as effective as root-applied $\mathrm{Si}$ in controlling powdery mildew (Blumeria graminis f. sp. tritici) on wheat. Liang et al. (24) found

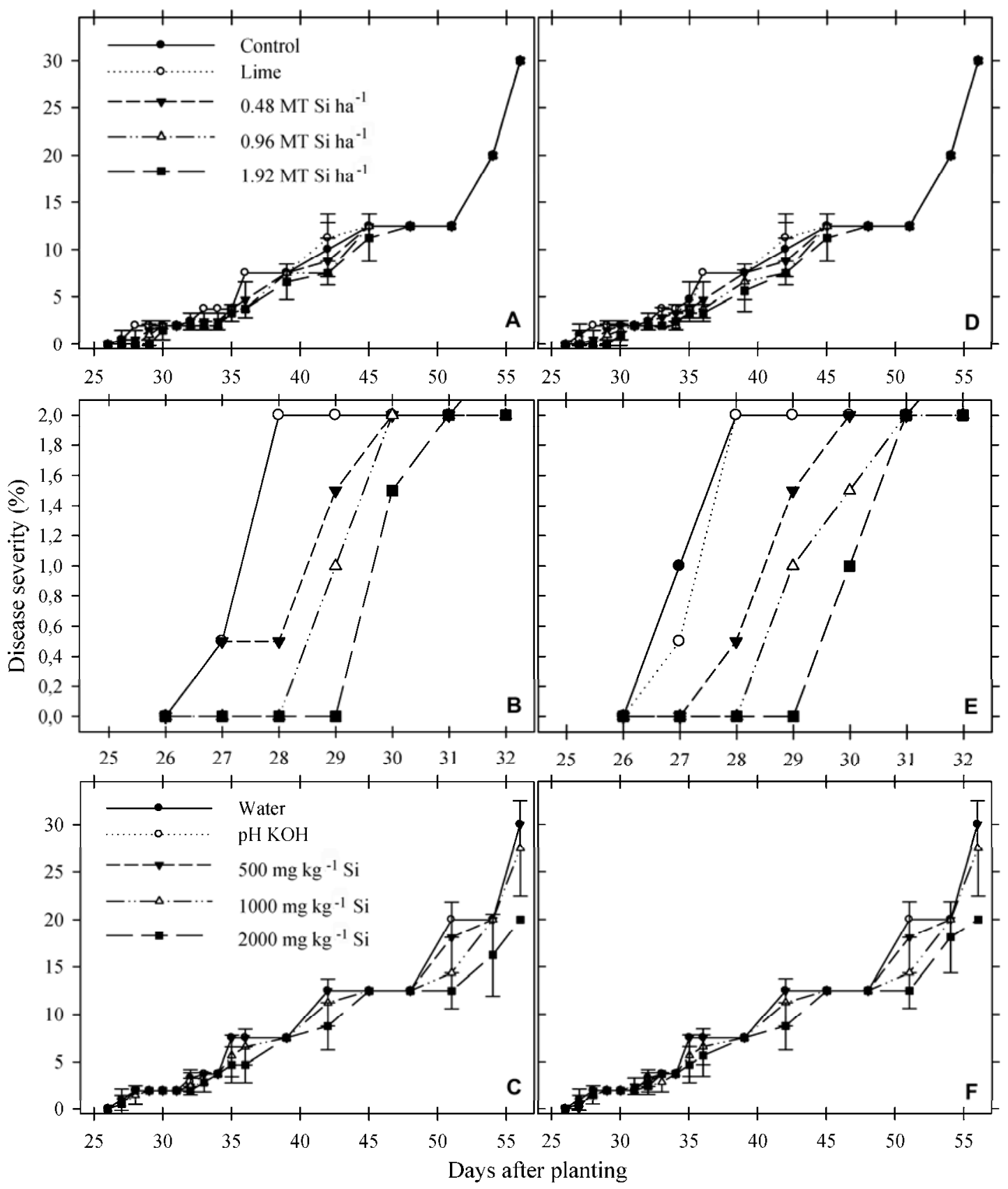

Fig. 5. Disease progress of soybean rust in 2008 for A, B, and C, cv. DP5634RR and D, E, and F, cv. Hinson Long Juvenile treated with A, B, D, and E, soil applied wollastonite - silicon (Si) at $0.48,0.96$, and $1.92 \mathrm{tha}^{-1}$ or $\mathbf{C}$ and $\mathbf{F}$, foliar applied potassium silicate - Si at 500, 1,000, and 2,000 $\mathrm{mg} \mathrm{kg}^{-1}$ and controls: Control (Si at 0 t ha-1), Lime $\left(8 \mathrm{tha}^{-1}\right)$, Water $\left(\mathrm{Si}\right.$ at $\left.0 \mathrm{mg} \mathrm{kg}^{-1}\right)$, and $\mathrm{pH} \mathrm{KOH} \mathrm{(pH}$ adjusted with $\mathrm{KOH}$ ) solution treatments. Vertical bars = with standard deviation of mean bars. Foliar Si treatments were applied the 29, 42 , and 55 days after planting. The first days of soybean rust progression from the soil Si treatments are magnified to show the delayed in disease onset ( $\mathrm{B}$ and $\mathrm{E})$. 
analogous results for powdery mildew ( $S$. fuliginea) on cucumber when $\mathrm{Si}$ was applied foliarly. The authors also reported that no enhancement of pathogenesis-related protein activity was observed for foliar Si applications, indicating that disease control promoted by the foliar treatments was likely a physical effect of the Si being deposited on the cucumber leaf or an osmotic or $\mathrm{pH}$ effect of the $\mathrm{Si}$ solutions on the leaf surface. The application of foliar Si may physically coat the leaf surface after drying, interfering with urediniospore germination and penetration and, as a consequence, controlling SBR development (19).

Si and SBR resistance. Another mechanism proposed to explain the role of $\mathrm{Si}$ in mediated disease resistance is that $\mathrm{Si}$ can modulate resistance within the plant. Studies of different pathosystems showed that plants amended with Si increased production and accumulation of phytoalexins and phenolic compounds that are toxic to pathogen development $(2,42)$. Together with the Si physical barrier, the production of pathogen-toxic compounds mediated by the presence of soluble $\mathrm{Si}$ increases the plant's natural defense mechanisms, thereby reducing disease damage. However, Pereira et al. (36) reported that foliar application of potassium silicate reduced SBR severity when compared with the control but did not increase the activity of soybean defensive enzymes. The fact that greater concentrations of leaf Si retarded SBR onset does not necessarily prove a cause-and-effect relationship between a physical protection and reduced disease; therefore, further studies are necessary to confirm the actual mechanism of soybean resistance against SBR initial development.

In another study where $\mathrm{Si}$ and a sugarcane rust disease were investigated, mixed results were observed (37). Raid and his colleagues (37) observed that Si had no influence on sugarcane brown rust development. They proposed that, because Puccinia melanocephala infects via stomates and not directly through the cuticle, this may be why $\mathrm{Si}$ did not effectively suppress brown rust development. However, the levels of brown rust severities observed in this 2-year study were $13 \%$ or less and perhaps disease levels were not high enough to detect treatment differences. In a more recent study (31), both foliar- and soil-applied $\mathrm{Si}$ were tested to determine their efficacy in suppressing sugarcane brown rust development in South Africa, where brown rust severity was found to be reduced from $85 \%$ in the control plants to $64 \%$ in sugarcane plants treated via soil $\left(\mathrm{CaSiO}_{3}\right)$ and foliar $\left(\mathrm{K}_{2} \mathrm{SiO}_{3}\right)$ applications.

$\mathrm{Si}$ accumulation in soybean. Dicotyledonous plants, like soybean, can take advantage of the benefits that Si provides against many biotic and abiotic stresses, even though it may be accumulated in relatively low concentrations $(8,42)$. In the field studies, the soybean leaves accumulated Si to approximately $3,500 \mathrm{mg} \mathrm{kg}^{-1}$, while leaf accumulation was as great as $6,000 \mathrm{mg} \mathrm{kg}^{-1}$ in the first greenhouse study. Our values (Tables 1, 2, and 3) agree with Miyake and Takahashi (30), who observed leaf $\mathrm{Si}$ values as great as

Table 4. Integrated area under disease progress curve (AUDPC) for soybean rust in the 2007 and 2008 field experiments ${ }^{\mathrm{z}}$

\begin{tabular}{lll}
\hline & \multicolumn{2}{c}{ AUDPC } \\
\cline { 2 - 3 } Treatments & $\mathbf{2 0 0 7}$ & $\mathbf{2 0 0 8}$ \\
\hline Soil Si $\left(\mathrm{t} \mathrm{ha}^{-1}\right)$ & $280 \mathrm{abc}$ & $387 \mathrm{c}$ \\
Lime $\left(8 \mathrm{t} \mathrm{ha}^{-1}\right)$ & $315 \mathrm{a}$ & $384 \mathrm{c}$ \\
0 & $214 \mathrm{de}$ & $357 \mathrm{~d}$ \\
0.48 & $227 \mathrm{cde}$ & $340 \mathrm{e}$ \\
0.96 & $181 \mathrm{e}$ & $324 \mathrm{f}$ \\
1.92 & & \\
Foliar Si $\left(\mathrm{mg} \mathrm{kg}^{-1}\right)$ & $295 \mathrm{ab}$ & $417 \mathrm{ab}$ \\
KOH $(\mathrm{pH} 10.4)$ & $297 \mathrm{ab}$ & $418 \mathrm{a}$ \\
$0(\mathrm{DI}$ water $)$ & $247 \mathrm{bcd}$ & $412 \mathrm{~b}$ \\
500 & $211 \mathrm{de}$ & $382 \mathrm{c}$ \\
1,000 & $189 \mathrm{de}$ & $337 \mathrm{e}$ \\
2,000 & &
\end{tabular}

${ }^{z}$ Values sharing the same letter, within the same year, did not differ significantly at $P \leq 0.05$ as determined by the Fisher's protected least significant difference test.
$8,400 \mathrm{mg} \mathrm{kg}^{-1}$ in hydroponic culture, depending upon solution $\mathrm{Si}$ concentration and the period of Si supply.

In the first greenhouse study, both soybean cultivars had approximately twice the leaf $\mathrm{Si}$ concentration compared with the second greenhouse study or field studies. The first greenhouse study differed from the others in that an inert, soilless potting mix was used and yet the extractable soil Si was similar among studies, thereby suggesting that bioavailable Si was similar between potting mix and soil. When comparing between the two greenhouse studies, the first study was terminated at 69 DAP whereas the second one lasted only until 34 DAP. The longer growing period in the first greenhouse study probably contributed to the observed greater Si uptake. In contrast, the repeated field experiment lasted at least 80 days but had leaf Si concentrations below 3,500 $\mathrm{mg} \mathrm{kg}^{-1}$ over both years. Crops grown in the field typically go through a transpiration depression (stomatal closure) during early afternoon (period of greatest solar radiation and vapor pressure deficit). This likely can result in less $\mathrm{Si}$ movement through plants grown in the field (25). Additionally, under well-watered conditions (such as with the greenhouse experiments), positive substrate turgor pressure will pump nutrients through plants during the night (i.e., guttation). In soils that are below field capacity (i.e., the field studies in 2007 and 2008), this was much less likely to occur.

Another unusual result from these studies is that cv. DP5634RR demonstrated greater leaf Si concentrations than cv. Hinson Long Juvenile in the greenhouse study but had relatively lower concentrations in the field. Because the field studies lasted through full maturity and DP5634RR matures at least 2 weeks earlier than Hinson Long Juvenile, the discrepancy may simply be a matter of DP5634RR having less time to accumulate $\mathrm{Si}$. In contrast, the greenhouse experiments were terminated prior to full maturity. These preliminary data warrant additional research into the effect that cultivar-environment may have on Si accumulation.

Conclusions. The use of $\mathrm{Si}$ amendments, such as wollastonite and potassium silicate, is an environmentally friendly strategy for sustainable crop production. However, further research on control of SBR that includes Si application timings or combinations of $\mathrm{Si}$ amendments with other fungicides or organic approved products, such as copper sulfate, needs to be performed. Si has been shown to improve host plant resistance and suppress other diseases as effectively as some fungicides (44-46). In these reported studies, $\mathrm{Si}$ was able to reduce both the number and rate of application of fungicides, and the combination of $\mathrm{Si}$ and fungicides always was the most effective in suppressing disease development. Therefore, a combination of disease control strategies may be the best approach to reduce production costs and optimize control practices in locations where soil Si is inherently low.

Since SBR discovery in North America in 2004, the late onset of disease experienced in the major soybean production areas has resulted in reduced economic impact. Any further delay in disease during the growth cycle of the soybean will benefit both organic and conventional soybean producers.

\section{Acknowledgments}

We thank the students, staff, and faculty of North Florida Research and Education Center-University of Florida-IFAS, Quincy, and the Plant Pathology Department at the University of Florida, Gainesville, for their excellent support; and W. Klassen (Center of Tropical Agriculture), United States Department of Agriculture Cooperative State Research, Education, and Extension Service, and Iowa State University (Organic Fungicide Project) and the University of Florida's Plant Pathology Department for their financial and operational support.

\section{Literature Cited}

1. Baylis, A. D., Gragopoulon, C., and Davidson, K. J. 1994. Effects of silicon on the toxicity of aluminum to soybean. Commun. Soil Sci. Plan. 25:537546.

2. Belanger, R. R., Benhamou, N., and Menzies, J. G. 2003. Cytological evidence of an active role of silicon in wheat resistance to powdery mildew (Blumeria graminis f. sp. tritici). Phytopathology 93:402-412.

3. Belanger, R. R., Bowen, P. A., Ehret, D. L., and Menzies, J. G. 1995. Soluble silicon: its role in crop and disease management of greenhouse crops. Plant Dis. 79:329-336.

4. Bowen, P., Menzies, J., and Ehret, D. 1992. Soluble silicon sprays inhibit 
powdery mildew development on grape leaves. J. Am. Soc. Hortic. Sci. 117:906-912.

5. Bromfield, K. R. 1984. Soybean Rust. Monogr. 11. American Phytopathological Society, St. Paul, MN.

6. Datnoff, L. E., Deren, C. W., and Snyder, G. H. 1997. Silicon fertilization for disease management of rice in Florida. Crop Prot. 16:525-531.

7. Datnoff, L. E., and Rodrigues, F. A. 2005. The role of silicon in suppressing rice diseases. APSnet Feature. Online publication. http://www.apsnet.org/ publications/apsnetfeatures/Pages/SiliconInRiceDiseases.aspx

8. Datnoff, L. E., Rodrigues, F. A., and Seebold, K. 2007. Silicon and plant disease. Pages 233-246 in: Mineral Nutrition and Plant Disease. L. E. Datnoff, W. H. Elmer, and D. M. Huber, eds. American Phytopathological Society, St. Paul, MN.

9. Elliott, C. L., and Snyder, H. 1991. Autoclave-induced digestion for the colorimetric determination of silicon in rice straw. J. Agric. Food Chem. 39:1118-1119.

10. Epstein, E. 1999. Silicon. Annu. Rev. Plant Physiol. Plant Mol. Biol. 50:641-644.

11. Florida Automated Weather Network. 2009. Report Generator, Quincy. http://fawn.ifas.ufl.edu/data/reports/

12. Guével, M. H., Menzies, J. G., and Bélanger, R. R. 2007. Effect of root and foliar applications of soluble silicon on powdery mildew control and growth of wheat plants. Eur. J. Plant Pathol. 119:429-436.

13. Hartman, G. L., Saadaoui, E. M., and Tschanz, A.T., eds. 1992. Annotated Bibliography of Soybean rust (Phakopsora pachyrhizi Syd.). Asian Veg. Res. Dev. Cent. Library Bibliogr. Ser. 4-1. Tropical Vegetable Information Service, Taipei.

14. Hartman, G. L., Sinclair, J. B., and Rupe, J. C. eds. 1999. Compendium of Soybean Diseases, 4th ed. American Phytopathological Society, St. Paul, MN.

15. Horsfall, J. G., and Barratt, R. W. 1945. An improved grading system for measuring plant disease. (Abstr.) Phytopathology 35:655.

16. Isard, S. A., Gage, S. H., Comtois, P., and Russo, J. M. 2005. Principles of the atmospheric pathway for invasive species applied to soybean rust. Bioscience 55:851-862.

17. Jeger, M. J. 2004. Analysis of disease progress as a basis for evaluating disease management practices. Annu. Rev. Phytopathol. 42:61-82.

18. Kluthcouski, J., and Nelson, L. E. 1980. The effect of silicon on the manganese nutrition of soybeans [Glycine max (L.) Merrill]. Plant Soil 56:157160.

19. Koch, E., and Hoppe, H. H. 1988. Development of infection structures by the direct-penetrating soybean rust fungus (Phakopsora pachyrhizi Syd.) on artificial membranes. J. Phytopathol. 122:232-244.

20. Kochman, J. K. 1977. Soybean rust in Australia. Pages 44-48 in: Rust of Soybean-The Problem and Research Needs. R. E. Ford and J. B. Sinclair, eds. International Agricultural Publications, Manila, Philippines.

21. Levy, C. 2005. Epidemiology and chemical control of soybean rust in Southern Africa. Plant Dis. 89:669-674.

22. Liang, Y., and Shen, Z. 1994. The effect of silicon on the manganese nutrition of soybeans [Glycine $\max$ (L.) Merrill]. Plant Soil 56:157-160.

23. Liang, Y. C., Shen, Q. R., Shen, Z. G., and Ma, T. S. 1996. Effects of silicon on salinity tolerance of two barley cultivars. J. Plant Nutr. 19:173-183.

24. Liang, Y. C., Sun, W. C., Si, J., and Römheld, V. 2005. Effects of foliar- and root-applied silicon on the enhancement of induced resistance to powdery mildew in Cucumis sativus. Plant Pathol. 54:678-685.

25. Ma, J. F., Nishimura, K., and Takahashi, E. 1989. Effect of silicon on the growth of rice plant at different growth stages. J. Plant Nutr. Soil Sci. 35:347-356.

26. Ma, J. F., and Takahashi, E. 2002. Soil, Fertilizer, and Plant Silicon in Research in Japan. Elsevier Science, Amsterdam.

27. Marchetti, M. A., Melching, J. S., and Bromfield, K. R. 1976. The effects of temperature and dew period on germination and infection by urediospores of Phakopsora pachyrhizi. Phytopathology 66:461-463.

28. Melching, J. S., Dowler, W. M., Koogle, D. L., and Royer, M. H. 1989. Effects of duration, frequency, and temperature of leaf wetness periods on soybean rust. Plant Dis. 73:117-122.

29. Menzies, J. G., Ehret, D. L., Glass, A. D. M., Helmer, T., Koch, C., and Seywerd, F. 1991. Effects of soluble silicon parasitic fitness of Sphaerotheca fuliginea on Cucumis sativus. Phytopathology 81:84-88.

30. Miyake, Y., and Takahashi, E. 1985. Effect of silicon on the growth of soybean plants in a solution culture. J. Plant Nutr. Soil Sci. 31:625-636.
31. Naidoo, P. V., Caldwell, P. M., and McFarlane, S. 2008. Movement of silicon through Saccharum officinarum (sugarcane) and its effect on Puccinia melanocephala (brown rust). Page 79 in: 4th Silicon in Agriculture Conference Book of Abstract. South Africa.

32. Nascimento, J. F., Zambolim, L., Duarte, H. S. S., and Rodrigues, F. A. 2005. Effect of potassium silicate combined or not with systemic or protector fungicides on the control of Asian Soybean Rust. Page 121 in: III Silicon in Agriculture. G. H. Korndorfer, ed. Uberlândia, MG, Brazil.

33. Nolla, A., Korndörfer, G. H., and Coelho, L. 2006. Efficiency of calcium silicate and carbonate in soybean disease control. J. Plant Nutr. 29:2049 2061 .

34. Ogle, H., Byth, D., and McLean, R. 1979. Effect of rust (Phakopsora pachyrhizi) on soybean yield and quality in southeastern Queensland. Aust. J. Agric. Res. 30:883-893.

35. Pastor-Corrales, M. A., Liebenberg, M. M., Sartorato, A., and ArraesPereira, P. A. 2006. Reaction of common cultivars to the Asian Soybean Rust pathogen, Phakopsora pachyrhizi, under field conditions in South Africa and Brazil. Bean Improv. Coop. Annu. Rep. 49:31-32.

36. Pereira, S. C., Rodrigues, F. A., Carré-Missio, V., Oliveira M. G. A., and Zambolim, L. 2009. Aplicação foliar de silício na resistência da soja à ferrugem e na atividade de enzimas de defesa. Trop. Plant Pathol. 34:164-170.

37. Raid, R. N., Anderson, D. L., and Ulloa, M. F. 1992. Influence of cultivar and soil amendment with calcium silicate slag on foliar disease development and yield of sugarcane. Crop Prot. 11:84-88.

38. Reynolds, A. G., Veto, L. J., Sholberg, P. L., Wardle, D. A., and Haag, P. 1996. Use of potassium silicate for the control of powdery mildew (Uncinula necator (Schwein) Burrill) in Vitis vinifera L. cultivar Bacchus. Am. J. Enol. Vitic. 47:421-428.

39. Rezende, D. C., Rodrigues, F. A., Carré-Missio, V., Schurt, D. A., Kawamura, I. K., and Korndörfer, G. H. 2009. Effect of root and foliar applications of silicon on brown spot development in rice. Australas. Plant Pathol. 38(:67-73.

40. Rodrigues, F. A., Datnoff, L. E., Korndörfer, G. H., Seebold, K. W., and Rush. M. C. 2001. Effect of silicon and host resistance on sheath blight development in rice. Plant Dis. 85:827-832.

41. Rodrigues, F. A., Duarte, H. S. S., Domiciano, G. P., Souza, C. A., Korndörfer, G. H., and Zambolim, L. 2009. Foliar application of potassium silicate reduces the intensity of soybean rust. Australas. Plant Pathol. 38:366-372.

42. Rodrigues, F. A., McNally, D. J., Datnoff, L. E., Jones, J. B., Labbe, C., Benhamou, N., Menzies, J. G., and Belanger, R. R. 2004. Silicon enhances the accumulation of diterpenoid phytoalexins in rice: a biochemical mechanism for blast resistance. Phytopathology 94:177-183.

43. Sanchez, C. A. 1990. Soil-testing and fertilization recommendation for crop production on organic soils in Florida. Fla. Coop. Ext. Serv. Bull. 876.

44. Seebold, K. W. 1998. The influence of silicon fertilization on the development and control of blast caused by Magnaporthe grisea (Hebert) Barr, in upland rice. Ph.D. diss. University of Florida.

45. Seebold, K. W., Datnoff, L. E., Correa-Victoria, F. J., Kucharek, T. A., and Snyder, G. H. 2004. Effects of silicon and fungicides on the control of leaf and neck blast in upland rice. Plant Dis. 88:253-258.

46. Seebold, K. W., Kucharek, T. A., Datnoff, L. E., Correa-Victoria, F. J., an Marchetti, M. A. 2001. The influence of silicon on components of resistance to blast in susceptible, partially resistance, and resistant cultivars of rice. Phytopathology 91:63-69.

47. Shaner, G., and Finney, R. E. 1977. The effect of nitrogen fertilization on the expression of slow-mildewing resistance in Knox wheat. Phytopathology 67:1051-1056.

48. Soil Survey. 2009. Web Soil Survey: Gadsden County (FL039). http://web soilsurvey.nrcs.usda.gov/app/HomePage.htm

49. Sweets, L. E., Wrather, J. A., and Wright, S. 2004. Soybean Rust. University of Missouri-Columbia Coop. Ext. Bull. G4442.

50. Wright, D. L., Rich, J. R., Marois, J. J., Sprenkel, R. K. 2002. Soybean Production in Florida. Florida Cooperative Extension Service. http://edis. ifas.ufl.edu/ag185

51. Yoshida, S. 1965. Chemical aspects of the role of silicon in physiology of the rice plant. B. Nat. Inst. Agron. Sci. Ser. B 15:1-58.

52. Yu, Z., Tan, Y., and Sun, Y. 1994. Distribution and damage of soybean rust in China. In: Advance of Soybean Rust Research. Proc. Meet. Held in 1992. Department of Science and Technology, MAPRC, Asian Regional Center, AVRDC, and Oil Crops Research Institute, CAAS, eds. Hubei Science and Technology Publishing House, Hubei, People's Republic of China. 